\title{
REMEDIAL TEACHING PROGRAM FOR LOW-ACHIEVERS: AN EFL TEACHER'S PERCEPTION
}

\author{
Eko Noprianto \\ SMA Negeri 1 Kibang, Lampung Timur \\ Noprianto.eko@student.upi.edu
}

\begin{abstract}
In schools like in Indonesia in which the majority of the classrooms are dominated by students coming from various cultures, different personality, different learning strategies, different background knowledge, and different pace in learning as well, it is certainly difficult for the teachers to accommodate all students' needs which then results to have students who cannot reach the learning objectives. Thus, a remedial teaching program is demanded to address those failing students. However, the debate on whether or not remedial teaching was effective for low-achievers continued among scholars. Besides, the attention on remedial teaching programs in the Indonesian context was also limited. This case study involving one EFL teacher of a Junior High School in Riau was conducted to explore her perception of the remedial teaching programs and to find out what problems she encountered in conducting it. Using an interview supported with document analysis, the researcher found that although the teachers admitted that low-achievers benefited from remedial teaching programs, it was difficult for the teacher to design and conduct an effective remedial teaching programs mainly due to time limitation. Besides, the difficulty in simplifying teaching materials, students' learning overload and lack of school support were seen to be other problems encountered by her in conducting the program.
\end{abstract}

Keywords: 2013 curriculum, low-achievers, remedial teaching program

\section{A. INTRODUCTION}

ince teachers have the responsibility to help students become both intelligent and good, $\int$ it is such a relieving and enjoyable moment for teachers to know that their teaching works. Failing will certainly bother both teacher and students. However, in schools in which the majority of the classrooms are filled with students coming from various cultures, different personality, different learning strategies, different background knowledge, and different pace in learning as well, it is certainly difficult for the teachers to accommodate all students' needs which then results to have students who cannot reach the learning objectives (Lampard, 2006). Moreover, the chance to have students who fall behind the other students might be even bigger due to psychological problems such as lack of confidence, learning anxiety, and probably low self-esteem involving students (Arifin, 2017), not to mention the technical aspect like the size of the classroom, around thirty to forty students, which is obviously not ideal. Therefore, teachers would easily find some students who reluctantly learn, have poor motivation, are unable to comprehend learning material, have a short span of focus, and probably have other behavioral problems. As a result, it is not surprising to find some low-achievers, those who could not achieve learning objectives as stated in the beginning of the teaching semester or in the context of this study, the ones who are unable to reach the Kriteria Ketuntasan Minimal (KKM) 
or Minimum Achievement Criteria score, a targeted competence which should be achieved by Indonesian students in the form of numeral values (Dirjendikdasmen, 2015).

However, burdening those students and the classroom conditions with all blames seems to be exaggerating since there might also be problems with the way teachers deliver the teaching material as well as problems in managing all students with those aforementioned differences. Ironically, the fact that many teachers including EFL teachers only employ another test to deal with low-achievers is not helping. Giving more test is not a solution since students need to understand the concept of learning material. No matter how frequently teachers set the test, the improvement will not probably be significant. Therefore, besides doing a reflection of what has been done and what was probably wrong with the curricula and evaluation (Oyekan, 2013) for future improvement, teachers need to design a teaching and learning strategy to help those lowachievers to pass the targeted score in a short time as the assessment follow-up. As stated in Panduan Penilaian Kurikulum 2013 or the Evaluation Guidelines of 2013 Curriculum, it is clearly mentioned that all teachers should design a remedial teaching program which will be used to deal with the low-achievers and an enrichment program for those who already reach the learning objectives (Dirjendikdasmen, 2015).

However, whether or not remedial teaching program could really help low-achievers reach the learning objectives still becomes a topic to debate among scholars. Ndebele (2014), Othman and Shuqair (2013), and Sahito's et al. (2017), for instance, believed that the remedial teaching was proven to be ineffective and only a few students benefitted from the program. The ineffectiveness of the program was due to several factors such as the inadequate teaching material and poorly trained teachers to conduct remedial teaching combined with the poor supervision and monitoring from the stakeholders (Ndebele, 2014), students' negative attitude toward the program and the use of inappropriate teaching methods which kept being used by the lectures (Othman \& Shuqair, 2013), not to mention the time limitation and lack of logistical structure (Alghamdi \& Siddiqui, 2016).

Meanwhile, Selvarajan and Vasanthagumar (2012), on the other hand, found that remedial teaching was proven to be crucial to deal with low-achievers if delivered appropriately. Their findings were also in line with a study conducted by Jadal (2012) which compared a systematic remedial teaching program with traditional methods in dealing with low-achievers and the study conducted by Cheng (2014) in Taiwan context which elicited the students and instructors' perception on remedial teaching.

However, although remedial teaching program is seen crucial in dealing with low-achievers, the attention on remedial teaching program particularly in the context of Indonesian is still 
limited in numbers. Besides, some studies such as the ones by Alghamdi and Siddiqui (2016); Boatman and Long (2017); Cheng (2014); Jadal (2012); Othman and Shuqair (2013); Ndebele (2014); Sahito's et al. (2017); and Selvarajan and Vasanthagumar (2012) focused only on the effectiveness of remedial program from students' perspectives and seem unable to bring a deep and comprehensive exploration regarding EFL teachers' perception toward remedial teaching program which is arguably essential before conducting any programs to students. This study, on the other hand, would try to deeply investigate how an EFL teacher perceived remedial teaching as well as to find out what problems she encountered in designing and conducting the program. Considering all those aforementioned issues and theories, the researcher was interested in exploring how an EFL teacher perceived remedial teaching as well as to find out what problems she encountered in designing and conducting the program. This study would hopefully give some meaningful contributions to the Indonesian education in relation to the remedial teaching program implementation.

\section{B. REVIEW OF LITERATURE}

\section{Remedial teaching program}

Etymologically, remedial is derived from the word 'remedy' which means to heal, to repair, to fix and to repeat. Thus, remedial teaching is a process of teaching to heal and to repair the learning results which is not in accordance with stated learning objectives to get better results (Masbur, 2012). In more specific definition, Cheng (2014); Selvarajan and Vasanthagumar (2012) argued that remedial teaching is conducted to provide the students who cannot keep pace with the process of teaching and learning in normal classroom activities with the opportunities to get them at least similar results with those who already reach the targeted score. Inline to that definition, Cashdan and Pumfrey (2006); Jangid and Inda (2016) believe that remedial teaching is an effort to help students who need pedagogical or didactic assistance probably due to a certain learning or behavioral problem. In the context of Indonesia, Dirjendikdasmen (2015) in Panduan Penilaian Kurikulum 2013 (the Evaluation Guidelines of 2013 Curriculum) mentions that remedial teaching is the help for the students who have not achieved the Kriteria Ketuntasan Minimal (KKM) score. Based on those definitions, it is clear that the objective of remedial teaching is basically to make sure that all low-achievers are able to get the targeted learning competencies based on their characteristics and capabilities. As highlighted by Christenson and Thurlow (2004), remedial teaching should be designed to help students find a match between the classroom and school activities with their individual characteristics to meet the academics and behavior demand. 


\section{Conducting an effective remedial teaching}

In order to get a maximum result of remedial teaching, Makmun (2005) suggested seven procedures of conducting remedial teaching: (1) diagnosing students' learning difficulties in which, according to Djamarah and Zain (2002), it is considered to be the most important procedure in which the teachers could not skip because the teachers would get the pictures of what happens to the students and the possibility of how to deal with them, (2) deciding the actions dealing with students' problems, (3) providing students' with counselling if the students' problems seem to be complicated and could not be overcome by the regular teacher, (4) conducting remedial teaching to repair students' achievement which is below the targeted score (KKM), (5) measuring students' achievement (6) Re-evaluating and re-diagnosing, and (7) optionally, enriching.

In Indonesia's latest curriculum, 2013 curriculum, although the procedures of conducting remedial teaching are probably not comprehensive enough as the guidelines, it is mentioned that remedial teaching could be conducted through four possible ways: (1) Remedial teaching through different teaching methods and media, (2) Special treatment in which it is assigned if only several students who could not keep pace with the majority of the students in the classroom, (3) Assigning more special assignment to help the students get used to the types of test questions through intensive practice and assignment, and (3) Peer tutorial (Dirjendikdasmen, 2015).

\section{METHOD}

The current study is aimed at exploring a Junior High School EFL teacher's perception in remedial teaching programs and figuring out what problems the teacher might encounter in conducting it. To realize the objectives of the research, a qualitative case study approach was selected. The use of the qualitative case study in this present study is because the researcher intended to find out an intensive and holistic description and in-depth analyses of what really happened to remedial teaching implementation from an EFL teacher's perspective. As mentioned by Merriam (2009), a qualitative case study is appropriate if a researcher needs to understand a single entity or phenomenon comprehensively as it provides an intensive and holistic product of investigation. This is also in line with Hamied (2017) who stated that qualitative research is appropriate to be used when the researcher intends to explore feelings, values, and perceptions which affect behavior. 


\section{The context of the study}

This current study was conducted at a public Junior High School in Pekan Baru, Riau. The school, SMP Hebat (a pseudonym), was a newly-built school which was initially used 2013 curriculum before they decided to change it into school curriculum (KTSP) a year after that, due to the limited teaching and learning facilities and the inability of teachers to implement 2013 curriculum. The school had twelve classes with four classes for each grade. Each class consisted of thirty-eight students in which the majority of them came from parents who worked as traders. The classes were shared with four English teachers.

Regarding the participant of the study, the researcher purposefully selected the participant based on the following criteria: participant' experiences in teaching English and participant and the researcher's relationship. The participant's experiences of teaching are expected to give much information regarding how she perceived remedial teaching to deal with low-achievers. The focus of the study was not limited only on how the participant perceived, but also how she experienced it, her understanding toward remedial teaching, and what problems she might encounter in conducting remedial teaching as well. Moreover, the researcher assumed that the school in which the participant was teaching and the curriculum used might influence how she perceived remedial teaching. Meanwhile, since the openness of the participant while being interviewed was crucial to get much and deep information, the participant and researcher's relationship became another consideration.

Considering those criteria, an English teacher who taught seven grade students was selected. Ana (a pseudonym) is an experienced female teacher who has been teaching for almost ten years and has also been certified as a professional teacher. She also experienced in teaching in several schools with different characteristics before she ended up teaching in her current school starting from 2014. Three of the schools were public schools one of which was the one where she was teaching at the time of the study while the other two were private schools. The data of this current study were gained from her experiences in conducting remedial teaching in those aforementioned schools. This thirty-four-year-old participant is the researcher's colleague. Their relationship started when they together pursued their master's degree at an Indonesian university majoring English education at the time of this study. Their personal relationship was expected to lead to a certain openness in their interview process.

\section{Data collection and analysis}

The data were collected in through two methods: semi-structured interview as the main data collection supported by documents analysis. The semi-structured interview was used to dig 
information regarding Ana's perception and what problems she encountered in doing the remedial teaching. This semi-structured interview allowed the researcher to respond to the situation at hand, and to new ideas on the topic. Some questions were used to confirm the result of document analysis. This one-on-one interview was tape-recorded and transcribed verbatim to get an accurate record of the conversation while the researcher was making some brief notes during the interview. To complete the information related to Ana's remedial teaching program design, her lesson plans and semester program documents were analysed. The lesson plans and semester program documents are chosen because they contain how she planned to achieve teaching objectives. They also comprised teaching objectives, teaching material, teaching methods, assessment system as well as their remedial teaching plans. The analysis in this context only focused on remedial teaching plans section. Honestly, since this study tried to explore remedial teaching program implementation, the researcher should acknowledge that it would be more informative if this data collection was completed with an observation to see how it was conducted in a real situation. However, observation during November and December was difficult to realize since those months were the months when the school was having a final semester examination in the context of the academic year of Indonesia education system that the participant did not have time to be observed.

The interview was taken once and lasted around thirty minutes. The focus of the interview ranged to several topics which included her understanding on what made the students failed to reach targeted score, how she dealt with low-achievers, how she perceived remedial teaching program, how she conducted it, and what problems he encountered in doing remedial teaching program as well. The analysis results were also presented based on those aforementioned interview topics in sequence.

\section{FINDINGS AND DISCUSSION}

\section{Factors contributing to the students' failure in achieving the targeted score}

At the beginning of the interview, the researcher tried to figure out what made the students fail to reach the targeted score. He believed that what made the students fail was fundamental to be figured out since it might be useful for every teacher to find ways to solve it. In Ana's words:

There are two main causes why students cannot achieve the targeted score or KKM. Firstly, it is because the students have a mindset that English is a difficult subject to learn. Secondly, because of that mindset, the students then lack the motivation to learn which automatically makes them ignore what we teach. They then sometimes do not really care about what we teach (interview, Ana, p.1). 
Surprisingly, based on her statements, instead of mentioning technical issues such as teaching methodology, and lack of supporting facilities as the researcher would expect, she opted to dig the causes into a deeper problem. Her statements clearly indicated that the major problems that the students face were their negative perspective on the English subject that then led them to have low motivation to learn English. Although the statements were in her own opinion, it could be seen that she used the first person plural form 'we' which indicated that she tried to align her viewpoint to other teachers in general which meant that according to her, other teachers would share similar experience and perceptions. For her, the impact of low motivation made the students ignored what she was doing in the classroom and seemed to be not interested in the teaching activities. In other words, whatever teaching methods she applied in the classroom, the students would still be uninterested in learning.

In another opportunity, Ana even seemed to blame the low inputs that the school had from the first place as another cause of students' failure in achieving KKM score. In Anna's account:

In my school, the majority of my students have been low-achievers since they were from elementary schools. My school is newly built in that area so perhaps the students were not selected through a tight selection process. Almost all students who registered were accepted by the school. Some students are good but the majority of the students are low-achievers (interview, Ana, p. 3).

For Ana, it was important for a school to have a good admission process to capture good and quality students which was probably not conducted by the school where she taught. She also questioned how her school accepted the majority of the students who registered to the school. This statements might indicate that teaching the students who were academically low from the beginning was challenging and needed extra energy to conduct.

The information from Ana that low-achievers were influenced by their negative perspectives which led to low motivation and also by low inputs which her school gained seemed to be in line with Othman and Shuqair's (2013) study which found that students' negative attitude toward English language, their low of seriousness in learning and low motivation as well indeed influence the success of the students in learning the language. Meanwhile, Selvarajan and Vasanthagumar (2012) in their analysis about the reasons for low achievement preferred to mention the external factors such as lack of parents' support in their children's education and severe poverty as the main factors affecting students' low achievements, these external factors were mentioned to lead to the students' irregular attendance at school, for instance.

Knowing those problems, Ana admitted that the most important thing a teacher should do to address those low-motivated students was trying to attract the students' attention to her subject. In Ana's words: 
First of all, I try to make them love me, maybe, with my look or with my talking style or from the way I motivate them in order to make them interested in English. Secondly, perhaps, I try to design a teaching material and teaching activities as interesting as possible or as simple as possible that they can easily understand what they are learning that day (interview, p. 1).

Ana's utterances interestingly indicated that the most fundamental factor that should be paid more attention was how to maintain a good relationship between her and the students. Although she seemed to be uncertain with these, (see the use of hedging words such as 'maybe' and 'perhaps' in her statements), she believed that the opportunity to get students' interest in English is bigger if she changed the way she looked in front of the students, the way she talked to them, and the way she encouraged the students to keep learning. She also mentioned that it would be also beneficial if she could create a teaching material and design teaching activities which are as interesting and simple as possible.

In relation to teaching activities, the proceeding answer showed that she admitted that attractive teaching activities made the students happy to learn although the results of students' score did not increase too significantly. However, according to her, what mattered more at that moment was to see that the students' improvement in their interest in English. Knowing that the students were happy with teaching activities was considered as an achievement for her. As stated by Ana:

...when I bring a media such as video in the classroom, the students seem very happy. Although the result (the score) is not increasing significantly, that's my effort to interest them to learn English (Interview, Ana, p. 1).

\section{Remedial teaching program in Ana's viewpoint}

I mean, as I said before, there are many students who do not like learning English, who have different characteristics, so remedial teaching program is a program where I can review the teaching process so that low-achievers can comprehend teaching material I give (interview, Ana, p. 1).

When the researcher asked her about remedial teaching program, Ana believed that remedial teaching program was a program which was designed to re-arrange and evaluate teaching activities which had not been mastered by the students yet. She also said that the purpose of remedial teaching program was to help low-achievers to achieve learning objectives. The program should be able to cover students with different characteristics and interest in English. Her definition of remedial teaching program was in line with previously mentioned theories. Thus, it showed that she already had a good understanding of what function of remedial teaching program was.

In relation to the benefit that the students got from doing remedial teaching program, she insisted that remedial teaching program was helpful to assist low-achievers to understand the teaching materials better since the materials were taught more than once. In other words, 
repetition of learning the same materials made the students get a better score. In addition to that, she also mentioned that by having more interactions with those students in remedial teaching program, she could know her students better and they would have a good relationship with her, as the teacher. In her words:

Of course, they will understand more the teaching material because it is taught more than once (laughter). Secondly, because we often interact with them, they feel more closed to us (laughter) (interview, Ana, p. 3).

She also added that the remedial teaching program gave her a satisfaction as she could see that the student achieved the teaching objectives or passed targeted KKM score.

Although Ana's statement did not seem in line with Othman and Shuqair's (2013) explanation that students would not benefit from remedial teaching program if the teachers keep using the same teaching methods over and over and could not find a good way to teach students considering the short periods of time available, the information from Ana's point of view was considered to be in line with Cheng's (2014) analysis result which mentioned that remedial teaching was basically beneficial to the low-achievers' academic and emotional selfefficacy, a point which was important in the students' learning success. However, Cheng also emphasized that those benefits would only be gained if remedial teaching program was supported by the awareness of the students' to conduct individualized remedial program combined with teacher's direct supervision and an appropriate support system, something which is according to Ana, was quite difficult to find to her low-motivated students to try to improve their self-efficacy and her school which seemed not to pay more attention on this. From Ana's perspectives, it appeared that by conducting remedial teaching, she believed that it would not only improve students' academic scores but it would also be able to build her students' good emotional relationship with her when having interaction in remedial teaching program so that they would be encouraged and motivated to learn English.

Interestingly, when asked about whether all the teachers conducted remedial teaching for low-achievers, she honestly admitted that not all teachers conducted remedial teaching for those students.

No, not all teachers. It depends on the teacher. Some teachers do not conduct it and just give the students standard score (a minimum score which already passes the KKM score) because they think that when given remedial teaching, these low-achievers will still get a bad score or even worst score so conducting remedial teaching will be useless (laughter)...some teachers just give the low-achievers minimum scores only to fulfil their responsibility to submit the students' scores for a report (interview, Ana, p. 7).

From the interview, it could be understood that some teachers opted not to conduct remedial teaching program and preferred to give them minimum KKM score to meet the requirement to be reported to school and considered that they already achieved the learning 
objectives. Although this information might not be able to be generalized to all teachers as Ana said but by referring to 'some teachers', this information showed that there was indeed an interesting fact that some teachers thought that remedial teaching program was not the way they choose to help low-achievers. This information certainly could not emerge instantly without any reasons. Those teachers might decide to do this through their experiences in conducting remedial teaching before probably in previous years with different students which then led them to a conclusion that remedial teaching was not helping and probably burdening both teacher and students.

The interview results also showed that in conducting remedial teaching, the first thing that she usually did was to analyze what part or what indicator which has been mastered by the students. In her words:

After having an examination or having known the results of assignment the students do, I analyze them to see which part of the materials which the students have not mastered yet (interview, Ana, p. 2).

By doing so, she also found out which students who belong to low-achievers and need a remedy. After analyzing, she began to design a remedial program which she thought that it would help those low-achievers. If the majority of the students failed, she would design a teaching program with different methods of teaching and simplified teaching materials and assignment as well. In Ana's words:

If (I) found many (low-achievers), I need additional time to conduct remedial teaching to review the materials, only certain parts, of course. I try to make the materials easier for them (interview, Ana, p.1).

Meanwhile, a personal approach was also preferred by Ana if she thought that the materials were too difficult only for certain students. Albeit being time-consuming, a personal approach was probably helpful to deal with low-achievers who have a different pace of learning since they were extensively drilled out of the whole class in which their opportunity to ask what they had not understood yet was limited.

Her explanation showed that Ana had already had enough knowledge on the procedures of conducting remedial teaching program in which it was accordance to what Djamarah and Zain (2002), and Makmun's (2005) explanation that if the teacher needed to have an effective remedial teaching program, a teacher should start with diagnosing students' learning difficulties before deciding the actions dealing with students' problems. Diagnosing students' learning difficulties also offered an opportunity for the teacher to know which students who needed more help and their level of difficulty which affected the selection of the actions to be addressed to. 


\section{Problems in conducting remedial teaching program}

In addition, to be able to comprehensively derive information about what happened to the teacher in conducting remedial teaching, it was fundamental to also discuss Ana's problems regarding remedial teaching program. Based on the interview analysis, the researcher divided the problems into two: external problems and internal problems.

With respect to the external problems, it was found that the main barrier encountered by the teacher is the time limitation. As mentioned by Ana:

Adjusting to the time. I need to find spare time. The point is I have to finish remedial teaching before submitting all students' final scores after mid-semester or semester test (interview, Ana, p. 2-3).

She also added that:

...but sometimes, it becomes more complicated when some students fail at the first remedial teaching test and are also included in the second remedial teaching (interview, Ana, p. 3).

Her words explicitly pictured how she fought to help low-achievers to get a better score in a very limited time available. In one side, she only had a very little time to conduct a remedial teaching, but on the other side, she should be able to cover all students' problems which were sometimes complicated as some students found to still fail after being given a remedial teaching.

When asked about the possibility that the limited time issue was caused by her teaching planning, she answered that the curriculum policy which burdened the students with too many subjects in one time caused a great impact on students' achievement and time availability. In her words:

The students learn not only English but also other subjects. They have so many assignments to finish in almost at the same time. So we have to ask the students when they are ready to have remedial teaching (interview, Ana, p. 4).

What could be seen here was that it appeared that too many subjects which should be learned by the students with their different assignments limited the opportunity to conduct remedial teaching for English. It indirectly pushed the teacher to wait until the students have time to be available to have a remedial program. The decision to wait until they were ready to have a remedy certainly risked the chance to help them achieve learning objectives since there was no guarantee that they were ready or not. That also noted that burdening students with many subjects would lead to the difficulty for the students to make the priority in their studying programs which inevitably influenced their achievements.

Talking about the internal problem, it was found that teacher's difficulty in adjusting the time to conduct remedial teaching program was supported with the difficulty in simplifying teaching materials. By her account: 
So there is a problem related to time in designing remedial teaching program. Then, determining a simple learning material which could be easily understood by the students are very difficult. Very difficult for low-achievers (Interview, Ana, p. 5).

Besides having difficulty in adjusting the appropriate time to conduct remedial teaching, there was also a problem related to designing the program. From her statements, it was understood that she was aware that what she should do was to simplify the teaching materials in order to be easily comprehended by low-achievers. However, it needed time to prepare it and more importantly, there was a problem with the way to simplify teaching materials in a limited time. Her difficulty was intensified by the use of the repetition of adverbial degree 'very' to show us that this problem was something she really emphasized. The need to simplify teaching materials was already emphasized in Panduan Penilaian Kurikulum 2013 or the Evaluation Guidelines of 2013 curriculum that a teacher should be able to simplify teaching materials and simplified tests delivered together with different teaching methods (Dirjendikdasmen, 2015).

Regarding the remedial teaching planning, as seen in her prosem (semester program) and lesson plans documents, although it appeared that Ana explicitly included remedial teaching program and allocated specific time for a remedial teaching program in her prosem, she seemed to still have difficulty in realization. Confirming this, Ana once again said that the problem was laid on the time availability and she related the problem to the school's policy. In her words:

The problem is in the time. Good schools usually provide all teachers at least a week to prepare the program before being submitted to the schools, finishing the program together and making a workshop related to program designing. But our school does not do such a thing. We are just reminded that tomorrow we should bring this and that (laughter), bring a lesson plan, but the school does not make us do that. I'm sure we would do that if the school made us do so (interview, Ana, p.7).

In Ana's point of view, teachers might understand that they need to spare particular time only for low-achievers' remedy, but there were still many teachers who were not aware of what should be the priority for them, what should they prepare in the coming teaching process and how to manage the prepared time to be able to deliver all teaching materials effectively or allocate their time efficiently to accommodate all their works including regular teaching process, doing assessment, and conducting remedial teaching program for low-achievers. Therefore, the role of school policy was pivotal to help those teachers make use the time as efficiently as possible. Doing a workshop and encouraging the teachers to design and prepare the effective program from the very beginning along with how to implement it would be helpful according to her.

The information from Ana was basically in line with Ndebele's (2014) analysis in his study that the main problems faced by English teachers in designing and conducting remedial teaching program were mainly on timetabling and poorly trained teachers and lack of school supervision. 
This was also supported by Alghamdi and Siddiqui (2016) who mentioned time limitation and lack of logistical structure became the main barriers. Seeing these problems from broader perspectives, it could be understood that timetabling, difficulty in simplifying teaching materials, and students' learning overloads as mentioned by Ana, were intertwined and could be related to two major themes: teacher's professionalism and government policy which was realized by the school.

Teacher's professionalism is certainly needed to be able to conduct effective teaching process including how to deliver effective remedial teaching program. As a professional, a teacher should be armed with skills and qualifications which involve professional competence, pedagogical competence, personality competence and social competence (Suherdi, 2013). In relation to time limitation, for instance, it is related to teacher's pedagogical competence in which it refers to teacher's ability to restructure content knowledge for teaching purposes, and to plan, adapt, and improvise. Apart from many subjects that the students need to learn in one academic year, a professional teacher should be able to adjust and consider every aspect in teaching with the availability of time in which it should be planned long before the teaching process was started. A professional teacher should be able to predict that there must be some students who would fail considering the different characteristics of the students, their different motivation, their different pace of learning, and probably the failure of teacher's teaching methods which could not cover all students' needs as well. As mentioned by Othman and Shuqair (2013) that effective remedial teaching program is influenced by the implementation of strategic plans by the teacher.

However, blaming the teachers for this seems to exaggerate since there should be a support from the school and the stakeholders for teacher's professional development. As a teacher works under the system run by the school, a good school should be able to facilitate and give ongoing support to both teachers and the students' needs. As stated by Richards (2002), an institution such as schools and language course has pivotal roles to create effective teaching since it is where the teaching process takes place, it provides rules, purpose and can enforce rules of human behavior. Regarding teacher's difficulty in timetabling, simplifying the teaching materials, and student's learning overloads, for example, there should be a role which the school could do in this context. A school could provide the teachers opportunities to develop their skills by providing some activities such as observation of experienced teachers, observation of training videos, short theory courses, a workshop on teaching planning, practice teaching under the supervision, and or working with a mentor teacher. As teachers develop experience in teaching, the institution also needs to create an environment in which teachers can further 
develop their teaching skills and subject-matter knowledge, deepen their understanding of teaching and themselves as teachers, and have the opportunity for further professional development.

\section{E. CONCLUSION}

The case study presented in this paper was an effort to figure out the remedial teaching program in an English teacher's perspective. It was also aimed at discovering the problems the participant encountered in conducting remedial teaching programs. Summing up from the analysis, it could be understood that failing students or the ones who could not achieve KKM in this study context are influenced by their negative perspectives on English subject from the first place which leads to the low motivation to learn the subject and low inputs which the school had. Therefore, interesting teaching activities and teacher's approaches are needed to gain students' attention toward English subject. The study also discovered that, according to the participant, both teacher and low-achievers benefit from the remedial teaching programs. However, some problems such as time limitation, teacher's difficulty in designing appropriate and simplified teaching materials, students' learning overloads, and lack of school support challenge the effectiveness of conducting remedial teaching programs.

Taking everything into consideration, some recommendations here are probably needed to consider. Teachers, EFL teachers in particular, for instance, need to understand that indeed, there is no size fit all and the chance to have low-achievers considering every aspect and condition of schools, students' diversity and school's lack of supports are inevitable. However, they should need to realize that they also need to improve their teaching expertise and competencies including how to design and plan remedial teaching programs to deal with those low-achievers since the responsibility to help those low-achievers is mainly on their shoulders supported with the appropriate school's policy which facilitates it. Besides, the researcher admits that the result of this present study is limited in the sense that it could not see remedial teaching programs implementation in a real situation. Using observation to see the real conditions of remedial teaching implementation in the classroom would be beneficial to fill the gap. Besides, since this study does not cover how the students perceive this remedial teaching program, it might be interesting to analyse it from the students' point of view for further study.

\section{REFERENCES}

Alghamdi, F. M. A., \& Siddiqui, O. (2016). Supporting low-achieving EFL learners: Expectations, procedure, and significance of remedial sessions at a Saudi University. Journal of Education and Training Studies, 4(12), 204-212. https://doi.org/10.11114/jets.v4i12.2028 
Arifin, W. L. (2017). Psychological problems and challenges in EFL speaking classroom. REGISTER JOURNAL, Language \& Language Teaching Journal, 10(1), 29-47. https://doi.org/10.18326/rgt.v10i1.29-47

Boatman, A., \& Long, B. T. (2017). Does remediation work for all students? How the effects of postsecondary remedial and developmental courses vary by level of academic preparation (NCPR Working Paper). National Center for Postsecondary Research, 20(10), 1 30. https://doi.org/10.3102/0162373717715708

Cashdan, A., \& Pumfrey, P. D. (2006). Some effects of the remedial teaching of reading. Educational Research, 11(2), 138-142. https://doi.org/10.1080/0013188690110208

Cheng, C. (2014). Individual differences: How remedial teaching transforms low-achievers when learning English. Journal of Modern Education Review, 4(11), 859-877. https://doi.org/10.15341/jmer(2155-7993)/11.04.2014/001

Christenson, S. L., \& Thurlow, M. L. (2004). School dropouts: Prevention considerations, interventions, and challenges. Current Directions in Psychological Science, 13(1), 36-39. https://doi.org/10.1111/j.0963-7214.2004.01301010.x

Dirjendikdasmen. (2015). Panduan penilaian untuk Sekolah Menengah Atas (SMA). Jakarta: Pusat Penilaian Pendidikan dan Pusat Kurikulum dan Perbukuan.

Djamarah, S. B., \& Zain, A. (2002). Strategi belajar mengajar. Jakarta: Rineka Cipta.

Hamied, F. A. (2017). Research methods: A guide for first-time researchers. Bandung: UPI Press.

Jadal, M. (2012). Developing skills of English through remedial package by low achievers at primary level. Journal of Arts and Culture, 3(2), 118-122.

Jangid, N., \& Inda, U. S. (2016). Effectiveness of remedial teaching on thinking strategies of slow learners. International Journal of Indian Psychology, 4(1), 98-105.

Lampard, D. M. (2006). Basic steps in remedial teaching. Educational Review, 2(3), 198-206. https://doi.org/10.1080/0013191500020304

Makmun, A. S. (2005). Psikologi kependidikan: Perangkat sistem pengajaran modul. Bandung: Remaja Rosdakarya.

Masbur. (2012). Remedial teaching sebagai suatu solusi: Suatu analisis teoritis. Didaktika, 12(2), 348-367.

Merriam, S. B. (2009). Qualitative research: A guide to design and implementation (2nd ed.). San Francisco: Jossey-Bass.

Ndebele, C. (2014). Teacher perceptions on the effectiveness of an English remedial teaching programme in primary schools in Zimbabwe: Towards an alternative to deficit model. International Journal of Education and Science, 6(3), 497-508. Retrieved from https://www.researchgate.net/publication/297758207\%0ATeacher

Othman, F. H. M. Al, \& Shuqair, K. M. (2013). Effectiveness of the remedial courses on 
Eko Noprianto, Remedial teaching Program for ...

improving EFL/ESL students' performance at university level in the Arab world. International Journal of Higher Education, 2(3), 132-138.

https://doi.org/10.5430/ijhe.v2n3p132

Oyekan, S. O. (2013). Effect of diagnostic remedial teaching strategy on students' achievement in Biology. Journal of Educational and Social Research, 3(7), 282-287. https://doi.org/10.5901/jesr.2013.v3n7p282

Richards, J.C. (2002). Curriculum development in language teaching. Cambridge University Press.

Sahito, Z., Siddiqui, A., Khawaja, M., Shaheen, A., Saeed, H., \& Laghari, S. H. (2017).

Teaching of remedial English and the problems of the students: A case of University of Sindh, Jamshoro, Sindh, Pakistan. World Journal of English Language, 7(1), 1-10. https://doi.org/10.5430/wjel.v7n1p1

Selvarajan, P., \& Vasanthagumar, T. (2012). The impact of remedial teaching on improving the competencies of low achievers. International Journal of Social Science \& Interdisciplinary Research, 1(9), 49-58.

Suherdi, D. (2013). Rekonstruksi pendidikan bahasa: Sebuah keniscayaan bagi keunggulan bangsa. Bandung: Celtics Press. 